\title{
ANALYSIS OF THE FACTORS THAT INFLUENCE EMPLOYMENT AS ONLINE TRANSPORTATION DRIVERS IN BATAM CITY
}

\author{
Evi Silvana Muchsinati ${ }^{1)}$, Marcerllina Teo ${ }^{2)}$ \\ ${ }^{1,2)}$ Universitas Internasional Batam, Indonesia \\ Corresponding author: evi@uib.ac.id
}

\begin{abstract}
The development of transportation is always followed by technological developments. The impact of changes in technological developments on online transportation is to provide opportunities for people to have new jobs. This research aims to analyze the influence of training, motivation, job stress, and job satisfaction on employee performance with employee engagement as a mediation. This study involves 400 employees of Gojek in Batam City. Using SmartPLS analysis, it was found that training is positive, not significant on employee performance with employee engagement as mediation. Job stress is negative, not significant on employee performance with employee engagement as mediation. Motivation and job satisfaction have the most critical role in enhancing employee performance, with employee engagement as mediation.
\end{abstract}

Keywords: Employee Performance, Employee Engagement, Online Transportation, Training, and Motivation

\section{Introduction}

It is a fact that transportation is essential for humans to make it easier for them to carry out daily activities. In the beginning, transportation was a basic necessity for humans and was used to move objects or humans from one point to another. However, now transportation cannot be separated from humans, especially for people who need transportation in the economic, social, and cultural fields. Before, transportation was driven by human or animal power. However, with the development of technology, transportation is constantly undergoing rapid changes. According to (Muharram 2019), the world's first transportation technology was the emergence of vehicles with steam engines in the $1870 \mathrm{~s}$. These changes and technological developments will certainly encourage progress in the transportation sector. The development of transportation that follows technological advances has provided many benefits and great opportunities for humans. The form of online transportation that is known and recognized by the public is online motorcycle transportation, which is used as moving an object or person from one destination to another by using an internet-based online system where every transaction activity starts from ordering, observing road routes, payments, and evaluating the services. The impact of changes in technological developments on online transportation is to provide opportunities for people to have new jobs. Online transportation is more effective and can improve the conventional transportation work system.

Based on the results obtained from the Central Statistics Agency (BPS) of Batam City, it is known that 54,018 people are unemployed. According to Nanda Muliansyah, from the August 2018 period, the total working-age population was 927,011 , of which 604,831 people were the workforce. If seen from the number of the crew, 54,018 people were a group of the labor force that hasn't worked. It was also stated that of the total unemployment, there was an increase of 8.93 percent or as much as 6,654 people compared to the number of unemployed in 2017.

Online transportation does not limit the number of drivers, and drivers only require a motorcycle as working capital. Being a driver of online transportation is also not limited to having a particular educational background. This will provide an opportunity for people in Batam City with an increasing unemployment rate. The issue of changing technological developments with online transportation is that many people want to register themselves as online motorcycle drivers. People who report themselves as online motorcycle drivers are people of various ages, genders, and professions. This is because most of them want to have more income and work with a flexible time. Based on this issue, there is a threat of loss of culture due to workers switching their profession to the online transportation sector, especially for art professionals who initially look for work related to artistic matters or activities. Concerns arise if art workers do not want to work as art professionals or are no longer interested in the art field, and are not satisfied with their income. Hence, they prefer to work as an online transportation driver.

The factors that cause online transportation drivers to increase are that the performance of online transportation employees can be influenced by the motivation given, job satisfaction, and training. These factors can involve employee engagement and can affect employee performance. Technology overgrowing has resulted in innovations from conventional transportation to online transportation. One online transportation, namely Gojek, existed in 2011 and started launching its application on mobile phones in 2015. Until 2018, there were around 175,000 drivers in Batam City.

The development of online transportation provides an opportunity to increase income for people in Batam City, supported by the facts provided based on data from (Gian, 2017) which states that people working as online transportation drivers can be influenced because the job does not require a lot of capital and the 
criteria that's relatively easy. Due to the increasing unemployment rate in Batam City, online transportation can provide work opportunities with this new job opportunity. (Gian, 2017) also said that based on data obtained through the Puskakom University of Indonesia, online transportation jobs can recruit workers who do not have jobs and recruit certain groups of the workforce. So, according to the research background above, this reserach aims to determine the effects of training, motivation, job stress, and job satisfaction on employee performance and employee engagement as a mediation.

\section{Literature Review \\ The Effect of Training on Employee Performance with Employee Engagement as Mediation}

Training plays a significant role in a company because the success and failure of organizational employees depend on their performance. It is considered that organizations are mostly more concerned with training their employees, knowing that it will help employees work more optimally to feel self-involved (Dahkoul, 2018). Training improves employee performance by developing a sense of teamwork among employees and contributing positively to knowledge and information about their work and contributes positively in increasing employees' knowledge of their jobs and enhancing the skills required for the job. It has an essential effect on employee engagement by indirectly involving employees in work activities such as conducting training needed by employees (Johnson et al., 2018). Training provides benefits for employees by improving skills, education, and attitudes to be more skilled so that they can achieve the company's goals, and employees can involve themselves in work by utilizing the skills that have been learned (Mardika, 2018). According to (Fahmi \& Hands, 2016), recent studies show employee training can increase their level of engagement with work, and this can be used as a factor for them to be involved in their work. When employees gain knowledge in adding insight and improving skills in their work, they will be more confident in doing so, and it will help increase employee engagement.

\section{The Effect of Motivation on Employee Performance with Employee Engagement as Mediation}

Motivation is a person's desire or interest to do something, which can be shown by a person's activity or ability to fulfill several requirements. A motivated employee can be seen from whether he feels satisfaction from the results of his work, self-achievement, and commitment between the company and himself, which creates better quality work and respects the policies or regulations of the company that will broadly realize competitive advantage. Motivation is defined as a psychological boost that controls a person's level of effort and persistence in dealing with work barriers. Employees will involve themselves with the organization to achieve a common goal or target (Shaaban, 2018). Employee motivation affects employee engagement so that motivation in both intrinsic and extrinsic forms needs to be done to create high employee work involvement by doing work that they consider attractive and can develop the performance of successive jobs (Endayani et al., 2018). One of the theories of motivation is the hierarchy of needs which is proposed by Abraham Maslow, which explains the importance of employee motivation because it is an essential component for the company. Because it is one of the most critical elements for employees to achieve success, targets, and organizational goals (Setiyani et al., 2019). Motivation is an internal feeling that comes from a person and is also essential in business activities. Highly motivated employees will involve themselves in work and perform better (Imran et al., 2014).

\section{The Effect of Job Stress on Employee Performance with Employee Engagement as Mediation}

Researchers (Fumio, 2000) mentioned that employees who experience job stress could be seen from several elements such as being given too much workload, time pressure that exceeds the time it should be given, and the role of ambiguity. These elements can impact employees not realizing that they have a big responsibility for their duties and jobs because most of them think that they have stress, so it is difficult to involve themselves in their job duties. Stress is seen as an unwanted phenomenon by a person which is caused by inadequate handling, work environment and is also a reaction to psychological and physical factors as well as internal and external factors of situations in which an individual's adaptability may be overextended (Aboazoum et al., 2015). If management does not acknowledge employee performance, the employee's job stress level will persist or will not get treatment, which will impact employee involvement in work. Employees obtain job stress from work environment conditions that have threatened employee engagement and performance. Job stress can be divided into various sources and can have an impact in several ways. One of them is that employees become unfocused on their work and feel dissatisfied with the organization's heavy and many assignments.

\section{The Effect of Job Satisfaction on Employee Performance with Employee Engagement as Mediation}

When employees like their jobs and their company, this study found that employees will be more involved in their work, so that employee satisfaction leads to employee engagement. Job satisfaction contains three components, namely the affective, cognitive, and behavioral components, which explain a person's feelings, beliefs, and behavior towards a job that can involve employees. Organizations that need performance improvements must focus on satisfying their employees. It is also defined as a positive feeling about a person's work results and many factors that affect job satisfaction, such as salary, relationships with 
management and fellow employees, working conditions, and regulations (Endayani et al., 2018). Between job satisfaction and employee engagement shows a close relationship, and allowing employees to involve themselves in their work can increase employee job satisfaction. Employees feel satisfied when the organization succeeds in conveying their individual goals with organizational goals, and the process also attracts them to be more involved in their work because they feel satisfied that the achievement of organizational goals will ultimately result in the accomplishment of their purposes (Swarnalatha \& Prasanna, 2014).

\section{The Effect of Employee Engagement on Employee Performance}

Employee engagement can be a component and a cause that affects employee performance. When employees are involved in their work, they will contribute positively to achieving organizational goals, but it only happens when the organization successfully reaches satisfaction. Employee engagement directly correlates with employee performance, making employees who are involved in work commit to their duties and work more effectively and efficiently (Ali et al., 2020). Employee engagement is one of the main determinants in maintaining and improving employee performance levels. It was also stated that employees involved in their work have a passion for their work and believe they have a deep connection to their organization. With the involvement of employees in performing their duties, it can improve employee performance properly. Highly committed employees to tend to perform better when compared to less committed employees (Arslan \& Roudaki, 2019).

Thus, figure 1 below demonstrates the proposed research model, where the relations between the variables.

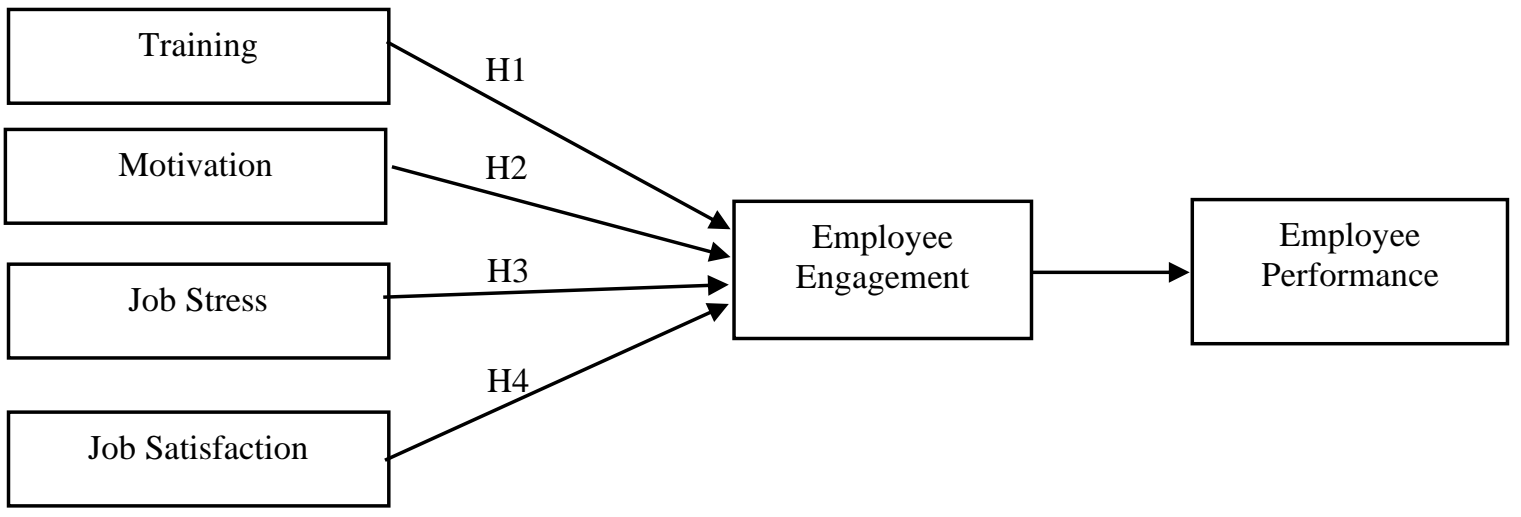

Figure 1. Proposed Research Model

According to the research model that has been compiled, below are the hypothesis :

H1: Training has a significant positive effect on employee performance with employee engagement as a mediation.

$\mathrm{H} 2$ : Motivation has a significant positive effect on employee performance with employee engagement as a mediation.

H3: Job stress has a significant positive effect on employee performance with employee engagement as a mediation.

H4: Job satisfaction has a significant positive effect on employee performance with employee engagement as a mediation.

\section{Research Methods}

In this study, they are using the non-probability methods as sample selection because using this method will save costs and time required compared to using random methods that require more time and higher costs. Purposive sampling is used in this study with specific criteria so that the sample taken by the researcher can be used in this study. The minimum sample will be determined, and it determines the minimum number of 384 based on the Krejcie and Morgan tables. However, to prevent missing questionnaires, answers to preliminary questions, or not returning questionnaires, the number of questionnaires to be distributed is 400 . Employees who work as online transportation drivers, especially motorcycle drivers, will be the population of this study. One of the reasons for choosing Gojek's motorcycle drivers is that in 2019, Gojek received a Top Brand Index of $44.6 \%$ for online transportation services in Indonesia. Therefore, the respondents of this study were online transportation, specifically motorcycle drivers in Batam City. The data analysis was used in SPPS and PLS.

Training must be adequate to ensure that employees can learn knowledge, skills, or something new useful for their job. The movement was measured using a five-point Likert scale with 4 questions adopted by (Shen \& Tang 2018). Motivation itself plays an essential role in the accomplishment of a company, and it is one of the critical elements that impact the human capital of any organization. The motivation was measured using a 
five-point Likert scale with a total of 3 questions adopted by (Swarnalatha \& Prasanna, 2014). Job stress is a situation where employees feel their psychological or physiological state and their mental are negatively affected functioning. Job stress was measured using a five-point Likert scale with a total of 13 questions which was adopted by (Tongchaiprasit \& Ariyabuddhiphongs, 2016). Job satisfaction refers to someone's feeling of satisfaction on a job which sees as a motivation to work. Job satisfaction was measured using a five-point Likert scale with 12 questions adopted by (Swarnalatha \& Prasanna, 2014). Employee engagement is where the employee feels involved and willing to commit to the company thoroughly. Employee engagement was measured using a five-point Likert scale with 4 questions adopted by (Swarnalatha \& Prasanna, 2014).

Employee performance is defined as how employees do their job and fulfill their job responsibilities and duties to achieve organizational goals. It refers to the effectiveness and quality of their work result. Employee performance was measured using a five-point Likert scale with a total of 3 questions adopted by (Siengthai \& Pila-Ngarm, 2016). The questionnaire was used to measure the accuracy of the data, which consisted of a few questions among those variables. On a five-point Likert scale, responses ranged from "strongly disagree=1" to "strongly agree $=5$ ".

\section{Result and Discussion}

The validity test results below show the overall AVE results, and six variables fall into the valid criteria. because it has AVE values, namely Training (0.847), Job Stress (0.950), Job Satisfaction (0.916), Employee engagement (0.872), motivation (1,00), Employee performance (0.859). The data processing reliability in the table below shows the calculation of composite reliability for the Training (0.584), Job Stress (0.598), Job Satisfaction (0.506), Employee engagement (0.696), motivation (1,00), Employee performance (0.673).

To assess the model fit, test whether there is a relationship between the independent, mediating, and dependent variables. The purpose of doing the determination coefficient test ( $\mathrm{R}$ Square), which is a part of the goodness of fit model, is to know the percentage of the fit of all models. This study tested two models to examine the relationships between direct and indirect effects, which refer to table 1 below. The relationship between the independent variables (training, motivation, job stress, and job satisfaction) and the mediating variable (employee engagement) on the dependent variable (employee performance) has an $\mathrm{R}$ Square value of $49.8 \%$, or it can be interpreted that employee performance is influenced by five variables. In comparison, the rest is $50.2 \%$, which has been influenced by other variables that are not in the model. While employee performance is influenced by independent variables (training, motivation, job stress, and job satisfaction), $33.9 \%$ and the remaining $66.1 \%$ from other variables. The model's path coefficients and indirect effects (full and partial) mediation results are shown in table 2 and table 3, below which the model showed an excellent overall fit on all indices.

Table 1. Determination Coefficient Test (R Square)

\begin{tabular}{cc}
\hline Variable & R Square \\
\hline Employee Engagement & 0.498 \\
\hline Employee Performance & 0.339
\end{tabular}

Source: Primary Data (2020)

Table 2. Specific Indirect Effects Result

\begin{tabular}{cccc}
\hline $\begin{array}{c}\text { Hypothesis } \\
\text { Number }\end{array}$ & Relationship & $\begin{array}{c}\text { Full Mediation } \\
\text { Specific Indirect Effects }\end{array}$ & T-Statistic \\
\hline H1 & P-KKA-KIK & 0.015 & 0.330 \\
\hline H2 & M-KKA-KIK & 0.085 & 3.119 \\
\hline H3 & SK-KKA-KIK & -0.026 & 0.713 \\
\hline H4 & KK-KKA-KIK & 0.335 & 5.485 \\
\hline
\end{tabular}

Source: Primary Data (2020)

Table 3. Path Coefficients Result

\begin{tabular}{cccc}
\hline $\begin{array}{c}\text { Hypothesis } \\
\text { Number }\end{array}$ & Relationship & $\begin{array}{c}\text { Partial Mediation } \\
\text { Path Coefficients }\end{array}$ & T-Statistic \\
\hline H1 & P-KKA & 0.027 & 0.329 \\
\hline H2 & M-KKA & 0.146 & 3.357 \\
\hline H3 & SK-KKA & -0.047 & 0.697 \\
\hline H4 & KK-KKA & 0.573 & 8.218 \\
\hline H5 & KKA-KIK & 0.581 & 10.820 \\
\hline
\end{tabular}

Source: Primary Data (2020)

Both of the results shown in table 4 and table 5 above show that motivation and job satisfaction positively influence employee performance with employee engagement as mediation (H2: path coefficient 0.146$)$ and (H4: path coefficient 0.573$)$. Employee engagement also positively influences employee performance $(H 5$ : 
path coefficient 0.581 ). While training is proved to be completely not significant ( $H 1$ : path coefficient 0.027 ) and job stress is negatively not significant (H3: path coefficient -0.047). The overall results support that employee engagement as a mediating variable can provide a good relationship between motivation and job satisfaction. Motivation and job satisfaction have the most crucial role in enhancing employee performance with mediation.

The main motive of this study was to examine the effect of training, motivation, job stress, and job satisfaction influences employee performance with employee engagement as mediation and examine employee engagement on employee performance. A research model was framed to describe the relationship between those variables. The results revealed that both motivation and job satisfaction was positively significant on employee performance with employee engagement as mediation and the results of this study are the same as research from (Mariza 2016), which means online transportation driver company (GoJek) must be able to provide and maintain the motivation that has been given either in the form of wages, bonuses, or other benefits to employees so that they have a sense of responsibility and involve themselves in their work. This shows that with a sense of motivation as an impetus for online transportation drivers in doing their job, the driver will create a sense of satisfaction generated in the work they are doing, so they will involve themselves in their daily work. The results of this study are the same as research from (Dahkoul 2018). Employee engagement was examined to be positively significant on employee performance. It shows that employees involving themselves in work with a sense of care and responsibility for their work will help improve the performance of employees. By having good performance and improving the performance of employees, of course, it can also enhance the image of the company or its brand to be better. It will also positively impact a company's progress, and the results of this study are the same as research (Alfajri, 2018).

Meanwhile, training (which means referring to the activity that is provided by the company itself) was proved to be positively not significant on employee performance with employee engagement as mediation, where some respondents think that the company does not provide good training opportunities such as the wrong training that is given by the company or the activity that is given is not sustainable. Training here to be proved not significant which can be caused by the wrong training method that has been provided, after talked and see the results from questionnaire being distributed, the author felt that good training means where GoJek company should be giving more training opportunities and conduct more training for their employees. The results of this study are the same as research from (Ningsi et al., 2016). Job stress was proved to be negatively not significant on employee performance with employee engagement as mediation, job stress itself is a word that sums up the situation in a negative manner, and the company must be able to minimize employees having job stress to achieve the desired performance, the results of this study are the same as research from (Alfajri, 2018) and (Noermijati \& Primasari, 2015).

\section{Conclusion}

This study contributes and tests to know each variable's influences and the relationships between them. This study can be helpful for companies to find out how to develop and design better strategies to increase the effectiveness of employee performance in the future. From this study, companies should be able to improve and maintain the achievements that have been achieved to keep encouraging their employees. This research shows that training must be sustainable given by the GoJek company for the drivers so that they will be helpful and improve in their daily work; for example, at least every six months there must be having training or evaluation of their performance due to maintaining the standard of their service. Certain limitations are acknowledged in this study, which is to expect conduct research on other independent variables that can be carried out in further investigation such as leadership variable because for the Gojek company itself, it has a person who leads the company until today which it will be interesting to be conducted in the following research.

\section{References}

Aboazoum, H. M. E., Nimran, U., \& Musadieq, M. Al. (2015). Analysis Factors Affecting Employees Job Performance in Libya. IOSR Journal of Business and ManagementVer. I, 17(7), 2319-7668. https://doi.org/10.9790/487X-17714249

Alfajri, O. (2018). Pengaruh Keterlibatan Kerja Dan Stres Kerja Terhadap Kinerja Karyawan Pada PT. PLN (persero) Distribusi Jawa Timur Area Surabaya Utara. Jurnal Ilmu Manajemen (JIM), 7(2), 516-523.

Ali, H. Y., Asrar-ul-Haq, M., Amin, S., Noor, S., Haris-ul-Mahasbi, M., \& Aslam, M. K. (2020). Corporate social responsibility and employee performance: The mediating role of employee engagement in the manufacturing sector of Pakistan. Corporate Social Responsibility and Environmental Management, February, 1-12. https://doi.org/10.1002/csr.2011

Arslan, M., \& Roudaki, J. (2019). Examining the role of employee engagement in the relationship between organizational cynicism and employee performance. International Journal of Sociology and Social Policy, 39(1-2), 118-137. https://doi.org/10.1108/IJSSP-06-2018-0087

Dahkoul, Z. M. (2018). the Determinants of Employee Performance in Jordanian Organizations. Pressacademia, 5(1), 137-143. https://doi.org/10.17261/pressacademia.2018.811

Endayani, F., Musadieq, M. Al, \& Afrianty, T. W. (2018). The Effect of Quality of Work-Life and Motivation on Employee Engagement with Job Satisfaction as an Intervening Variable. RJOAS, DOI 
Https://Doi.Org/10.18551/Rjoas.2018-02.12,30(February),108-114.

https://doi.org/10.6018/analesps.33.3.238551

Fahmi, A., \& Hands, D. (2016). The Taxi Service Review: Malaysia Context. Mediterranean Journal of Social Sciences MCSER Publishing, 7(4), 2039-9340. https://doi.org/10.5901/mjss.2016.v7n4p

Fumio, K. (2000). Impact of Job Stress on Health. 東京医科大学雑誌, 58(3), 364-366.

Gian, R. (2017). KMTM KOPROL : Seberapa Efektif Ojek Online Meningkatkan Taraf Hidup Masyarakat Indonesia? Kmtm.Ft.Ugm.Ac.Id. https://kmtm.ft.ugm.ac.id/2017/11/09/apakah-prospek-menjadipengemudi-ojek-online/

Imran, M., Maqbool, N., \& Shafique, H. (2014). Impact of Technological Advancement on Employee Performance in Banking Sector. International Journal of Human Resource Studies, 4(1), 57. https://doi.org/10.5296/ijhrs.v4i1.5229

Johnson, K. R., Park, S., \& Bartlett, K. R. (2018). Perceptions of customer service orientation, training, and employee engagement in Jamaica's hospitality sector. European Journal of Training and Development, 42(3-4), 191-209. https://doi.org/10.1108/EJTD-11-2017-0094

Mardika, N. H. (2018). Perangkat Nagari. 3(2), 182-195.

Mariza, I. (2016). The impact of employees' motivation and engagement on employees' performance of manufacturing companies in Jakarta Indonesia. International Journal of Applied Business and Economic Research, 14(15), 10611-10628.

Muharram, M. R. (2019). Mengenal Sejarah Perkembangan Transportasi Dunia. Ruang Guru. https://blog.ruangguru.com/sejarah-perkembangan-transportasi

Ningsi, C. A., Alhabsji, T., \& Utami, H. N. (2016). Pengaruh Pelatihan dan Promosi terhadap Motivasi dan Kinerja Karyawan ENGARUH (Studi pada Karyawan PT.PLN (Persero) Area Kendari). Jurnal Ilmiah Ilmu Administrasi Publik, 5(2), 131. https://doi.org/10.26858/jiap.v5i2.1765

Noermijati, N., \& Primasari, D. (2015). The effect of job stress and job motivation on employees' performance through job satisfaction (A study at PT. Jasa Marga (Persero) Tbk. Surabaya - Gempol branch). Journal of Economics, Business \& Accountancy Ventura, 18(2), 231. https://doi.org/10.14414/jebav.v18i2.450

Setiyani, A., Djumarno, D., Riyanto, S., \& Nawangsari, L. C. (2019). the Effect of Work Environment on Flexible Working Hours, Employee Engagement and Employee Motivation. International Review of Management and Marketing, 9(3), 112-116. https://doi.org/10.32479/irmm.8114

Shaaban, S. (2018). The Impact of Motivation on Organisational Citizenship Behaviour (OCB): The Mediation Effect of Employees' Engagement. Journal of Human Resource Management, 6(2), 58. https://doi.org/10.11648/j.jhrm.20180602.13

Shen, J., \& Tang, C. (2018). How does training improve customer service quality? The roles of transfer of training and job satisfaction. European Management Journal, 36(6), 708-716. https://doi.org/10.1016/j.emj.2018.02.002

Siengthai, S., \& Pila-Ngarm, P. (2016). The interaction effect of job redesign and job satisfaction on employee performance. Evidence-Based HRM, 4(2), 162-180. https://doi.org/10.1108/EBHRM-01-20150001

Swarnalatha, C., \& Prasanna, T. S. (2014). Employee Engagement and Job Satisfaction. Ijsr -International Journal of Scientific Research, 3(5), 339-340. https://doi.org/10.13140/RG.2.1.5050.6966

Tongchaiprasit, P., \& Ariyabuddhiphongs, V. (2016). Creativity and turnover intention among hotel chefs: The mediating effects of job satisfaction and job stress. International Journal of Hospitality Management, 55, 33-40. https://doi.org/10.1016/j.ijhm.2016.02.009 